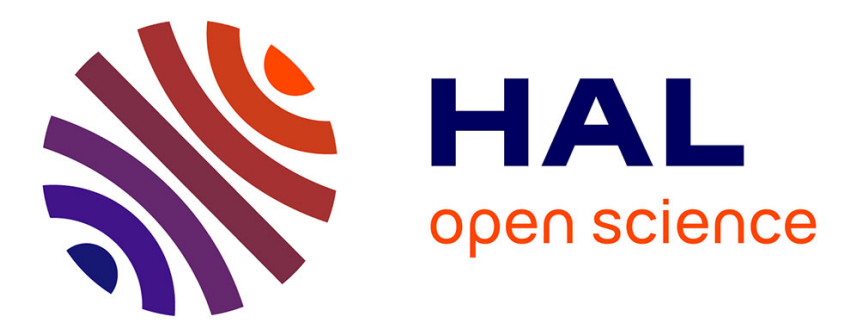

\title{
Positronium formation in solid acetylacetonate complexes
}

\author{
A. Porto, A. Marques-Netto, W.F. Magalhaes, C. Carvalho, J. Machado
}

\section{To cite this version:}

A. Porto, A. Marques-Netto, W.F. Magalhaes, C. Carvalho, J. Machado. Positronium formation in solid acetylacetonate complexes. Journal de Physique IV Proceedings, 1993, 03 (C4), pp.C4-205-C4208. 10.1051/jp4:1993429. jpa-00251472

\section{HAL Id: jpa-00251472 https://hal.science/jpa-00251472}

Submitted on 1 Jan 1993

HAL is a multi-disciplinary open access archive for the deposit and dissemination of scientific research documents, whether they are published or not. The documents may come from teaching and research institutions in France or abroad, or from public or private research centers.
L'archive ouverte pluridisciplinaire HAL, est destinée au dépôt et à la diffusion de documents scientifiques de niveau recherche, publiés ou non, émanant des établissements d'enseignement et de recherche français ou étrangers, des laboratoires publics ou privés. 


\title{
Positronium formation in solid acetylacetonate complexes
}

\author{
A.O.PORTO, A. MARQUES-NETTO, W.F. MAGALHAES, C.F. CARVALHO and J.C. MACHADO \\ Departamento de Química, ICEx, UFMG, C.P. 702, 31270901 Belo Horizonte M.G., Brazil
}

\section{ABSTRACTS}

Positron annihilation lifetime (LS) and Doppler broadening annihilation radiation lineshape (DBARL) were measured at room temperature in a series of solid acetylacetonate chelates involving metals of different groups. The LS and DBARL obtained parameters were associated with the electronic configuration of the central metal ions and their electronic spectra.

\section{INTRODUCTION}

Preliminary studies on a series of ranthanide
acetylacetonates and dipivaloylmethanates $(1,2)$, and on
coordination and organometallic transition metal complexes of the
nickel triad (3), have shown that the positron annihilation
parameters are sensitive to the liability of the solids to charge
tranfer process, conformation of the complexes, as well the
nature of both the central metal ion and the ligand.
With the purpose to obtain more information about these
subjects, we performed the study on a series of solid
acetylacetonate chelates of the groups IIA, IIIB, VB, VIB, VIIB,
VIIIB, IB, IIB and IIIA metals, using both LS and DBARL
techniques.

\section{EXPERIMENTAL}

The metal acetylacetonates were synthesized as described in the literature (4), with some modifications, when necessary. The complexes were purified by column chromatographic method, using cellulose as stationary phase and benzene as eluent. The characterization of the compounds was made by I.R. and powder $\mathrm{X}$-ray spectroscopies, by comparison with published data, and elemental analysis.

The lifetime spectrometer and positron source were described elsewhere (5). The lifetime spectra were satisfactorily analysed in three components, using the POSITRONFIT-EXTENDED program (6), 
leading to the intensities $\left(I_{i}\right)$ and lifetimes $\left(\tau_{i}\right)$ of the various positron states: subscripts 1,2 , and 3 will refer to parapositronium (p-Ps), free-positron and ortho-positronium (O-PS), respectively. The superscrit "o" denotes the parameters measured in the pure solid phase. The source correction was $10 \%$. In all cases, $\tau_{1}^{0}$ was fixed to $120 \mathrm{ps}$, the value for $p-P s$ self-annihilation. The intrinsic Ge detector (INTERTECHNIQUE) used for DBARL measurements has a resolution of $1.22 \mathrm{keV}$ (FWHM of the Sr-85, $514 \mathrm{keV}$ line) with an efficiency of $15.9 \%$ at 1.33 MeV. The parameter chosen for reporting DBARL results is the FWHM (full width at half maximum of the annihilation line), determined using the ANNPEAK program (7).

\section{RESULTS AND DISCUSSION}

The o-Ps yields $\left(I_{3}^{0}\right), F W H M$, and electronic configuration of the central metal ion of the studied complexes are summarized in Table 1 .

Table 1 - LS and DBARL parameters of metal acetylacetonates and the electronic configuration of the central metal ions (E.C.).

\begin{tabular}{|c|c|c|c|c|c|c|c|}
\hline $\begin{array}{l}\text { Compound } \\
\text { Class } 1\end{array}$ & $\begin{array}{l}I_{3}^{0} \\
(\%)\end{array}$ & $\begin{array}{l}\text { FWHM } \\
(\mathrm{keV})\end{array}$ & E.C. & $\begin{array}{l}\text { Compound } \\
\text { class } 2\end{array}$ & $\begin{array}{l}\mathrm{I}_{3}{ }^{0} \\
(\%)\end{array}$ & $\begin{array}{l}\text { FWHM } \\
(\mathrm{keV})\end{array}$ & E.C. \\
\hline $\mathrm{VO}(\mathrm{acac})_{2}$ & 1.8 & 2.88 & {$[\operatorname{Ar}] 3 d^{1}$} & $\mathrm{Al}(\mathrm{acac})_{3}$ & 44.0 & 2.44 & {$[\mathrm{Ne}]$} \\
\hline $\mathrm{Cr}(\mathrm{acac})_{3}$ & 2.6 & 2.76 & {$[\mathrm{Ar}] 3 \mathrm{~d}^{3}$} & $\mathrm{Ga}(\mathrm{acac})_{3}$ & 46.4 & 2.44 & {$[\mathrm{Ar}] 3 \mathrm{~d}^{10}$} \\
\hline $\operatorname{Mn}(\mathrm{acac})_{3}$ & 0.9 & 2.85 & {$[A r] 3 d^{4}$} & $\operatorname{In}(\mathrm{acac})_{3}$ & 46.2 & 2.50 & {$[\mathrm{Kr}] 4 \mathrm{~d}^{10}$} \\
\hline $\mathrm{Fe}(\mathrm{acac})_{3}$ & 0.7 & 2.88 & {$[\operatorname{Ar}] 3 d^{5}$} & $\mathrm{Be}(\mathrm{acac})_{2}$ & 27.0 & 2.46 & {$[\mathrm{He}]$} \\
\hline $\operatorname{Co}(\mathrm{acac})_{3}$ & 1.3 & 2.90 & {$[\operatorname{Ar}] 3 d^{6}$} & $\mathrm{Sc}(\mathrm{acac})_{3}$ & 26.2 & & {$[\operatorname{Ar}] 3 d^{0}$} \\
\hline $\operatorname{Rh}(\operatorname{acac})_{3}^{3}$ & 0.4 & 2.88 & {$[\mathrm{Kr}] 4 \mathrm{~d}^{6}$} & $\operatorname{Zr}(\operatorname{acac})_{4}^{3}$ & 29.4 & 2.51 & {$[\mathrm{Kr}] 4 \mathrm{~d}^{0}$} \\
\hline $\operatorname{Co}(\operatorname{acac})_{2}^{(a)}$ & 1.0 & 2.91 & {$[\operatorname{Ar}] 3 \mathrm{~d}^{9}$} & $Y(\operatorname{acac}) \underset{3}{(b)}$ & 38.9 & 2.49 & {$[\mathrm{Kr}] 3 \mathrm{~d}^{0}$} \\
\hline $\mathrm{Ru}(\mathrm{acac})_{3}$ & 1.5 & 2.83 & {$[K r] 4 d^{5}$} & $\mathrm{~cd}(\mathrm{acac})_{2}^{(a)}$ & 10.4 & 2.66 & {$[\mathrm{Kr}] 4 \mathrm{~d}^{10}$} \\
\hline
\end{tabular}

(a) Dihydrate compound ; (b) Trihydrate compound

As can be seen in Table 1 we can separate the studied metal acetylacetonates in two classes :

class $1-$ Ps formation is not observed in appreciable amount and $I_{3}^{-}$values for this class are extremely small, ascompared with the corresponding values for the other class. The $\tau_{3}^{0}$ values for these compounds are larger than $1.8 \mathrm{~ns}$ and poorly 
repproducible. This kind of behaviour have been already observed in many solids with $\mathrm{I}_{3}<5 \%$; therefore, little significance is ascribed to these parameters (5). The experimental FWHM values obtained for this class, in the range of $2.76-2.90 \mathrm{keV}$, are compatible with many other results in solid $(8,9)$ and liquid phases (10) where the Ps formation is very low, or no Ps is formed.

class 2 - Ps formation is observed in appreciable amount. The $I_{3}^{0}$ values are very large, and the $\tau_{3}^{0}$ values are in the range $1.00-1.40$ ns. The experimental FWHM values for the compounds of this class are smaller than the corresponding value for the water $(2.66 \mathrm{keV})$ indicating the presence of a narrow component attributed to p-Ps.

The metal ions of the complexes of the class 1 have incompletely filled $3 d$ or $4 d$ orbitals in contrast with the completely filled or empty $3 \mathrm{~d}$ or $4 \mathrm{~d}$ orbitals of the metal ions of the chelates of the class 2 . The experimental UV-visible spectra for the compounds of class 1 show two characteristic types of electronic transition: charge tranfer and $d-d$ transitions, inexisting in the electronic spectra of the compounds of the Class 2 (see Fig.1a and Fig.1b, as typical examples). These results suggest that the electronic transitions observed in the metal complexes of class 1 , particulary the d-d transitions, may be closely associated with the inability of Ps formation in this class of compounds.

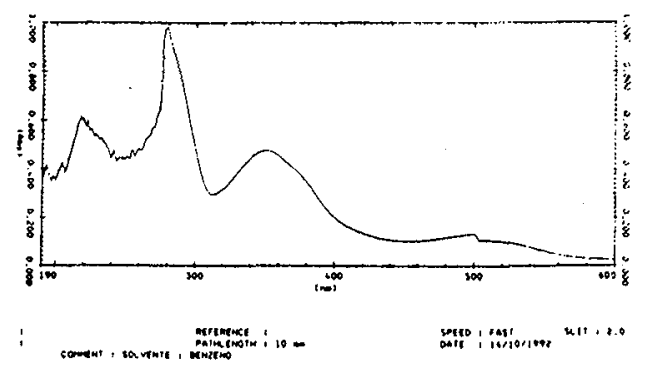

Fig.1a - The electronic absorption spectrum $\mathrm{Rh}_{(\operatorname{acac})_{3}(\mathrm{Class} 1)}$

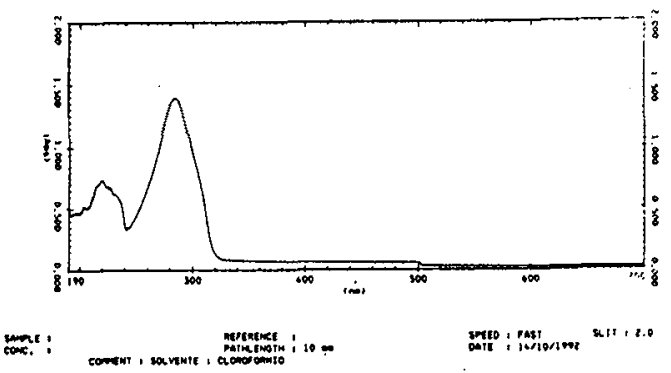

Fig.1b -The electronic absorption spectrum of $\mathrm{Ga}(\mathrm{acac})_{3}$ (Class 2) 
The only found exception is the Ir(acac) 3 (not showed in Table 1). This complex presents all spectroscopic characteristics of the compounds of class 1: incompletely filled 5d orbitals ( $\left.[\mathrm{Xe}] 5 \mathrm{~d}^{6}\right)$, charge transfer and $d-d$ transitions. However, this complex shows significative Ps yields $\left(I_{3}^{\circ}=27.0 \%\right.$ and FWHM $=$ $2.57 \mathrm{keV}$ ). The shielding effect promoted by the filled $4 \mathrm{f}$ orbitals may be responsible for this peculiar behaviour. Moreover, differently from the complexes of class 1 which are inhibitors or quenchers, the $\operatorname{Ir}(\mathrm{acac})_{3}$ is rather inert as inhibitor or quencher when diluted with $\mathrm{Al}$ (acac) ${ }_{3}$ matrix in the binary solid solution $\mathrm{Al}_{(1-\mathrm{x})} \operatorname{Ir}_{(\mathrm{x})}$ (acac) $_{3}$ (see reference 11 ).

REFERENCES

/1/MARQUES-NETTO,A.; MAXIMO BICALHO,S.M.C.; MACHADO,J.C.; FANTINE,E.O.; ABBE, J.Ch.; DUPLÂTRE,G., Chem. Phys. Letters 141 $(1987), 198$.

/2/MARQUES-NETTO,A.; MACHADO,J.C.; MAXIMO BICALHO,S.M.C.; FANTINE, E.O.; ABBE, J.Ch. and DUPLÂTRE, G., in POsitron Annihilation, 8 th ICPA, eds. L. Dorikens-Vanpraet, M. Dorikens and D. Segers (World Scientific, singapore, 1989) p. 815.

/3/KLEIN, S.I. ;BARBIERI,R.S.; NETTO,A.M.; SILVA,M.E.S.R. and MACHA- DO,J.C., J. Braz. Chem. SOC. 1 (1990) 80.

/4/CHALMERS, R.A. and MOHAMMAD U., Anal. Chim. Acta 42 (1968) 357. /5/MACHADO, J.C. ; CARVALHO,C.F.; MAGALHAES,W.F.; NETTO,A.M. ; ABBE, J.Ch. and DUPLÂTRE G., Chem. Phys. 170 (1993) 257.

/6/KIRKEGARD,P. and ELDRUP,M., Computer Phys. Commun.7, (1974), 401 .

/7/KELLY,J.J. and LAMBRECHT,R.M. "Positronium and Muonium Chemistry", ACHE,H.J. ed. Adv, in Chem. Ser., Amer. Chem. Soc., Washington, D.C. (1979) 175.

/8/TALAMONI,J.; ABBÉ,J.C.; DUPLÂTRE,G.; \& HAESSLER,A. Radiat. Phys. Chem. 21 (1983) 431.

/9/TALAMONI,J.; ABBE,J.C.; DUPLÂTRE,G. \& HAESSLER, A. Radiat. phys. Chem. 20 (1982) 275.

/10/MAGALHAES,W. F.; ABBE, J.C.; and DUPLÂTRE,G. Chem Phys. 136 (1989) 141./11/MACHADO,J.C.; PORTO,A.O.; CARVALHO, C.F.; MAGALHAES,W.F. \& MARQUES -NETTO A., "Positron annihilation studies in binary solid solutions of metal beta-diketonates using Lifetime and Doppler Broadening spectroscopies", 4Th INTERNATIONAL WORKSHOP ON POSITRON AND POSITRONIUM CHEMISTRY, Le Mont Sainte-Odile, France (1993).

[Acknowledgements to FAPEMIG, CAPES and CNPq] 